УДК 336

DOI: https://doi.org/10.26642/jen-2020-1(91)-123-132

Ю.С. Костишин, аспірант

Державний університет «Житомирська політехніка»

\title{
Концептуальні засади формування системи фінансової безпеки держави
}

\author{
(Представлено: д.е.н., проф. Педченко Н.С.)
}

\begin{abstract}
Статтю присвячено дослідженню концептуальних засад формування системи фінансової безпеки держави. Неоднозначність у підходах науковців щзодо тлумачення фінансової безпеки $i$ трактування ї̈ складових, відсутність у існуючій Концепції забезпечення національної безпеки у фінансовій сфері в Україні чітких визначень категоріально-понятійного апарату з иієї предметної області обумовлює актуальність теми статті та визначає ї̈ цільову спрямованість. Метою статті є очінка теоретичних підходів до фінансової безпеки держави та формування ї̈ концептуальної моделі на підставі застосування методології системного підходу. Визначено основні теоретичні підходи до фінансової безпеки держави: 1) суб'єктний підхід, який досліджує ї̈ з позииії реалізачії односпрямованих інтересів основних суб'єктів фінансових відносин, ще сприяють зростанню фінансового потенщіалу держави; 2) об'єктний підхід, який визначає фінансову безпеку в контексті фінансових потоків (ресурсів, джерел), щяо пронизують всю фінансову систему країни; 3) інституційний підхід з позииї дослідження фінансової безпеки на рівні інститутів та органів влади, які мають здатність забезпечувати стійкість економічного розвитку держави; 4) системний підхід, орієнтований на формування рівнів та підсистем фінансової системи держави, що передбачає їх рівномірний розвиток при прийнятому рівні фінансової безпеки. Методологічною основою дослідження фінансової безпеки автором обрано системний підхід, щзо обумовлено важливістю його вивчення як складного взаємозв'язку окремих підсистем, рівнів та елементів системи, щзо дасть можливість досягнути позитивного системного ефекту. Сформовано концептуальні засади формування системи фінансової безпеки, яка складається з трьох взаємопов'язаних підсистем: 1) функціонально-цілььової, яка містить принципи, мету (стратегічну та оперативну), завдання та функиії системи фінансової безпеки; 2) суб'єктно-об'єктної (рівні, суб 'єкти та об'єкти фінансової безпеки, диференційовані за виокремленими рівнями); 3) забезпечувальної, яка містить кадрове, нормативно-правове, методологічне, організаційне та інформаційне забезпечення. Перспективи подальших наукових досліджень варто пов'язати із детальним вивченням елементів запропонованої структури та визначенням системного ефекту від їх взаємодіi.
\end{abstract}

Ключові слова: фінансова безпека; держава; система фінансової безпеки; загрози.

Постановка проблеми у загальному вигляді та їі зв'язок з важливими практичними завданнями. Прийнятний рівень фінансової безпеки держави є основним критерієм ефективної економічної політики держави та формування сприятливих умов для активізації діяльності суб'єктів господарювання. Значення фінансової безпеки значно зростає в сучасних умовах впливу глобалізації, коли роль держави трансформується та посилюється вплив світових фінансових систем на окремі держави. У таких умовах фінансову безпеку можна сприймати як головну умову здатності уряду країни реалізувати самостійну фінансову політику держави відповідно до його національних інтересів. Водночас не існує однозначного підходу науковців щодо тлумачення фінансової безпеки, трактування ії̈ складових, а у випадку дослідження iii з системних позицій - у трактуванні іï окремих підсистем та елементів. Частково це пов'язано 3 відсутністю в існуючій Концепції забезпечення національної безпеки у фінансовій сфері в Україні чіткого визначення категоріально-понятійного апарату з цієї предметної області.

Аналіз останніх досліджень та публікацій. Питання фінансової безпеки на макро- та мікрорівнях широко висвітлено в наукових працях вітчизняних та закордонних авторів: О.Барановського [1], В.Бойса [2], Д.Брадлоу [3], В.Бурцева [4], Н.Виговської [5; 30], О.Гривківської [7], М.Срмошенка [8; 9], Р.Кларка [6], С.Маєрса [14], В.М Мельника [16], Н.Наконечної [17], П.Райзинга [22], Л.Росса [24], Г.Шиназі [28] та інших.

Постановка завдання. Метою статті $є$ оцінка теоретичних підходів до фінансової безпеки держави та формування її концептуальної моделі на підставі застосування методології системного підходу.

Викладення основного матеріалу. Перша група авторів визначає фінансову безпеку як створення умов стійкого, надійного функціонування всієї системи фінансів держави, регіону, що усуває виникнення фінансової кризи, дефолту, деструкцію фінансових потоків, збої у забезпеченні основних учасників економічної діяльності фінансовими ресурсами, порушення стабільності грошового обігу [21]. 
Досліджуючи змістовне навантаження терміна «фінансова безпека», В.В. Бурцев визначає його як окремий елемент економічної безпеки держави. Автор це пояснює тим, що в умовах становлення глобальних ринків посилюється і якісно трансформується вплив глобальних фінансових потоків на окремі держави [4].

Кондрат С. визначає фінансову безпеку держави як стан захищеності найбільш важливого елемента економічної безпеки держави. Він являє собою результат взаємодї органів різних гілок влади щодо захисту національних інтересів країни від зовнішніх та внутрішніх загроз у таких сферах, як бюджетна, податкова, валютна, грошова, інвестиційна та кредитна. Однак виникає питання, в чому ж полягає стан захищеності держави від зовнішніх загроз. Це можна трактувати таким чином: стан захищеності передбачає:

1) можливість уникнення або протистояння зовнішнім загрозам, які мають за мету зменшити рівень кредитоспроможності країни, підвищивши залежність від зовнішніх факторів;

2) забезпечення гнучкості законодавства при проведенні економічних перетворень;

3) задоволення потреби суб'єктів фінансових відносин у фінансових ресурсах, що забезпечить стійке зростання економіки країни;

4) забезпечення затвердженого рівня фінансової стійкості країни на деякий прогнозований період.

Поширеною $є$ позиція дослідження фінансової безпеки через ії складові види, орієнтуючись на макроекономічний рівень та процеси фінансового регулювання і контролю в країні. Наприклад, у системі фінансової безпеки можна виокремити: банківську, бюджетну, валютну, безпеку фондового ринку, кредитну [7; 16].

Одна з груп науковців визначає фінансову безпеку на мікрорівні, в центр дослідження якої поставлено рух фінансових ресурсів, пошук їх джерел та забезпеченість фінансовими ресурсами для нормального функціонування суб’єкта господарювання [26].

Бурцев В. пов'язує фінансову безпеку з інституціональною складовою держави і стверджує, що вона полягає у здатності державних органів [3]: 1) забезпечувати стійкість економічного розвитку держави в цілому; 2) забезпечувати стійкість платіжно-розрахункової системи; 3) нейтралізувати вплив зовнішніх загроз та фінансових криз (зменшувати негативний вплив інших держав, ТНК тощо); 4) попереджувати конфлікти між різними ланками влади 3 приводу формування, розподілу та використання бюджетних коштів; 5) залучати кошти іноземних інвесторів; 6) попереджувати порушення та злочини у фінансових правовідносинах.

Уточнюючи поняття «фінансової безпеки держави», В.Койло [11] визначає іï як стан фінансової системи, який демонструє ступінь захищеності фінансовими ресурсами, що є достатніми для задоволення суспільних потреб та виконання існуючих зобов'язань, враховуючи захищеність інтересів суб'єктів на усіх рівнях фінансових відносин від внутрішніх та зовнішніх загроз, а також забезпечує фінансові умови для стабільного соціально-економічного розвитку та пї стійкість до фінансових шоків, що, на відміну від існуючих, враховує формування фінансової безпеки на різних економічних рівнях. Можна повністю погодитися з позицією вченого про доцільність дослідження фінансової безпеки на всіх рівнях фінансової системи, оскільки необхідним є забезпечення рівномірного розвитку різних ії ланок для стабільності функціонування системи в цілому. Однак часто інтереси цих суб'єктів є різноспрямованими, що вимагає розробки механізму гармонізації таких інтересів та нівелювання протиріч. Єрмошенко М. [9], на відміну від попереднього науковця, трактує поняття «фінансової безпеки» як стан фінансово-кредитної сфери в цілому, що виражається у збалансованості і якості системної сукупності фінансових інтересів, достатності фінансових ресурсів для всіх суб'єктів господарювання і населення в цілому. Автор стверджує, що це сприятиме забезпеченню ефективного функціонування національної економічної системи і їі соціальному розвитку. Таке визначення фінансової безпеки також акцентує увагу на дотриманні інтересів всіх суб'єктів фінансової системи, шо є обгрунтованим. Однак потребує додаткового уточнення поняття «якості системної сукупності фінансових інтересів», зазначене у визначенні.

Незважаючи на необхідність врахування до предмета дослідження фінансової безпеки не лише національних інтересів держави, але й інтересів інших суб'єктів фінансової системи, в деяких наукових працях іiі розглядають звужено. Зокрема, в монографії [8] акцент зроблено виключно на рівні захищеності державних інтересів.

Сухоруков А.І. у своїй монографії визначає фінансову безпеку держави як захищеність інтересів держави у фінансовій сфері, або такий стан бюджетної, податкової та грошово-кредитної систем, що гарантує спроможність держави раціонально використовувати фінансові ресурси [27].

3 позиції системного підходу досліджує фінансову безпеку О.Савицька: «... фінансова безпека є складною багаторівневою системою, яку утворює ряд підсистем, кожна 3 яких має власну структуру і характер розвитку» [25]. В подальшому автор досліджує фінансову безпеку через ії складові підсистеми, а саме: бюджетну, валютну, грошово-кредитну, боргову безпеки, безпеку страхового ринку та безпеку фондового ринку. Це дозволяє сформувати авторське бачення досягнення безпечного рівня функціонування фінансової системи через рівномірний розвиток всіх її суб’єктів. 
Мелих О. визначає фінансову безпеку як «... надзвичайно складну багаторівневу систему, яку утворюють підсистеми (бюджетна, податкова, боргова, фінансова безпека банківської системи, валютна, грошово-кредитна, інвестиційна, фінансова безпека страхового та фондового ринку), кожна 3 яких має власну структуру і логіку розвитку» [15]. Науковий підхід, орієнтований на декомпозицію системи фінансової безпеки з метою оцінки загроз фінансовій системі, вважаємо перспективним.

Під системою фінансової безпеки розуміють створення таких умов іiі функціонування, за яких: 1) незначна імовірність переорієнтації фінансових потоків у незаконні сфери їх використання; 2) незначна імовірність зловживання фінансовими коштами [10]. Отож, найчастіше фінансову безпеку досліджують у контексті таких підходів: 1) реалізації односпрямованих інтересів основних суб'єктів фінансових відносин, які сприяють зростанню фінансового потенціалу держави (суб'єктний підхід); 2) фінансових потоків (ресурсів, джерел), що пронизують всю фінансову систему країни (об'єктний підхід); 3) інститутів та органів влади, які мають здатність забезпечувати стійкість економічного розвитку держави (інституційний); 4) рівнів та підсистем фінансової системи держави, що передбачає їх рівномірний розвиток при прийнятному рівні фінансової безпеки (системний).

За методологічну основу дослідження фінансової безпеки доцільно обрати системний підхід. Це обумовлено доцільністю іiї дослідження як складного взаємозв'язку окремих підсистем, рівнів та елементів системи, що надасть можливість одержати позитивний системний ефект.

Системний підхід спрямовує дослідника на розкриття цілісності об'єкта, що аналізується, й виявлення всіх його зв'язків [19]. Водночас методологічна основа та інструментарій системного підходу $\epsilon$ універсальними, що обумовлює можливість їх застосування до систем будь-якої природи, враховуючи соціальні.

Деякі автори [12], використовуючи поняття «система» до фінансової безпеки, пропонують різновид системного підходу - системно-потоковий методологічний підхід, орієнтований на концепцію управління фінансовими потоками на підприємстві. Автори це обгрунтовують наявністю тісного взаємозв'язку між видами фінансових ресурсів, фінансовими потоками, фінансовими результатами та досягнутим рівнем фінансової стійкості.

Загальноприйнятим фактором є те, що методологія системного підходу в основі має такі основні принципи:

- багатоплановості, що дозволяє дослідити будь-який об’єкт з різних позицій та аспектів. Це дає змогу досліджувати певну систему як частину системи більш високого порядку, у випадку фінансової безпеки як підсистему економічної безпеки країни в цілому;

- багатомірності, що передбачає дослідження фінансової безпеки як складного об'єкта, що характеризується складною структурою та специфічними властивостями, які дозволяють застосувати класифікацію системи за різними ознаками;

- ієрархічності, що передбачає наявність ієрархічної структури у досліджуваного об'єкта. Зокрема, цей принцип розповсюджується і на окремі підсистеми та елементи системи фінансової безпеки;

- динамічності, який означає, що в основу функціонування системи покладено принцип розвитку, що можна розглядати як трансформацію окремих підсистем та елементів системи фінансової безпеки в часі;

- різнопорядковості, що дозволяє дослідити закономірності розвитку як цілісної системи фінансової безпеки, так і їі окремих підсистем та складових елементів.

Адаптацію принципів системного підходу у застосуванні до нашої предметної області досліджень системи фінансової безпеки - представлено в таблиці 1

Таблиця 1

Адаптація принцุипів системного підходу до системи фінансової безпеки держави

\begin{tabular}{|c|c|c|}
\hline $\begin{array}{l}\text { № } \\
\text { 3/ח }\end{array}$ & $\begin{array}{c}\text { Найменування } \\
\text { принципу } \\
\text { системного підходу }\end{array}$ & Адаптація до системи фінансової безпеки \\
\hline 1 & Багатоплановості & Фінансова безпека є підсистемою економічної безпеки держави \\
\hline 2 & Цілісності & $\begin{array}{l}\text { Фінансова система є водночас єдиним цілим (підсистемою різних } \\
\text { видових складових фінансової безпеки) }\end{array}$ \\
\hline 3 & Багатомірності & $\begin{array}{l}\text { Кожний елемент фінансової безпеки держави як системи має власні } \\
\text { властивості, відмінні від властивостей інших елементів }\end{array}$ \\
\hline 4 & Ієрархічності & $\begin{array}{l}\text { Фінансова безпека є складовою безпеки держави в цілому та складається } \\
\text { зі взаємопов'язаних підсистем різних рівнів }\end{array}$ \\
\hline 5 & Динамічності & $\begin{array}{l}\text { Фінансова безпека підлягає трансформації елементного складу під } \\
\text { впливом факторів зовнішнього та внутрішнього середовища }\end{array}$ \\
\hline 6 & Різнопорядковості & $\begin{array}{l}\text { Дозволяє вивчати закономірності розвитку як цілісної системи } \\
\text { фінансової безпеки, так і їі окремих підсистем і складових елементів }\end{array}$ \\
\hline
\end{tabular}


Основні концептуальні засади формування системи фінансової безпеки держави як системи $\epsilon$ такими: 1) основним системоутворюючим фактором формування та забезпечення фінансової безпеки $\epsilon$ рівень забезпеченості держави фінансовим потенціалом, здатним протистояти зовнішнім та внутрішнім загрозам; 2) фінансову безпеку необхідно досліджувати на всіх рівнях функціонування суб'єктів фінансових відносин, оскільки саме такий збалансований розвиток призведе до підвищення рівня стійкості фінансової системи в цілому; 3) основними передумовами забезпечення достатнього рівня фінансової безпеки є стійкість та розвиток фінансової системи в країні, а також можливість захисту інтересів всіх суб'єктів фінансових відносин; 4) фінансова безпека має забезпечуватися не лише економічними, але й правовими та політичними засобами і механізмами 3 метою формування сприятливого середовища для розвитку фінансової системи.

Системну модель фінансової безпеки держави представлено на рисунку 1.

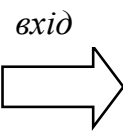

Загрози (зовнішні, внутрішні)

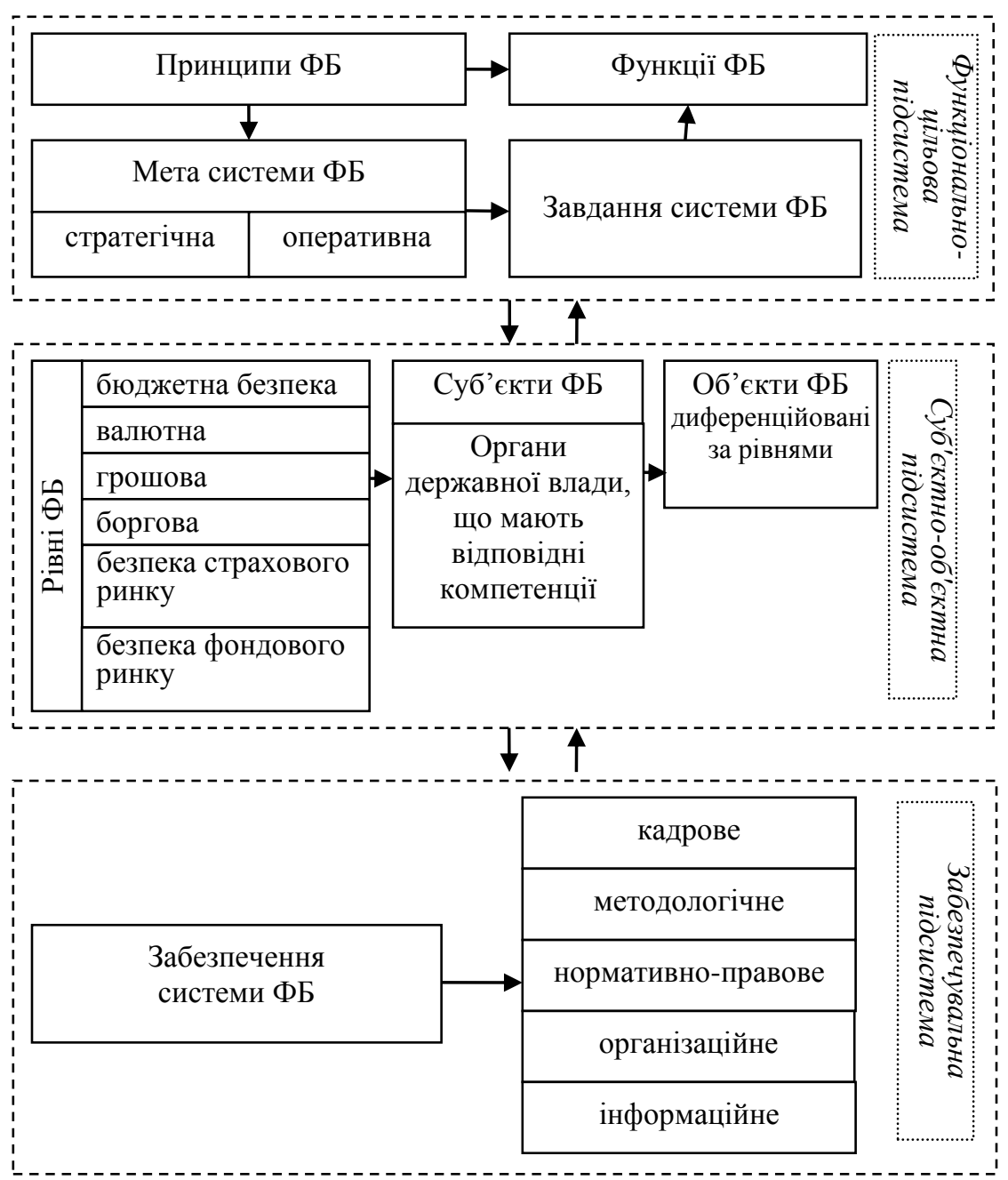

Індикатори

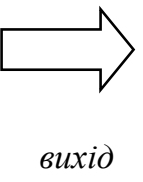

Рис. 1. Концеептуальні засади дослідження фінансової безпеки як системи (складено автором)

Наведемо основну характеристику елементів та підсистем сформованої системи фінансової безпеки. Система фінансової безпеки складається з трьох взаємопов'язаних підсистем: 1) функціонально-цільова підсистема, яка містить принципи, мету (стратегічну та оперативну), завдання та функції системи фінансової безпеки; 2) суб'єктно-об’єктна підсистема (рівні, суб'єкти та об'єкти фінансової безпеки, диференційовані за виокремленими рівнями); 3) забезпечувальна підсистема, яка містить кадрове, нормативно-правове, методологічне, організаційне та інформаційне забезпечення. Представлена система підлягає впливу загроз зовнішнього та внутрішнього середовища, негативному впливу яких система фінансової безпеки має протистояти та усувати його. Результатом функціонування запропонованої системи фінансової безпеки є індикатори та показники, що дозволяють оцінити дієвість системи.

Важливим елементом функціонально-цільової підсистеми фінансової безпеки є принципи як основні правила, покладені в основу іiі функціонування. Принципи фінансової безпеки містять: 1) загальні принципи системного підходу, адаптовані до нашої предметної області; 2) спеціальні принципи, до яких 
належать: законність, превентивність, адаптивність, динамізм, гнучкість. Характеристику спеціальних принципів системи фінансової безпеки представлено в таблиці 2.

Таблиияя 2

Характеристика спеціальних принцииів фінансової безпеки як системи

\begin{tabular}{|c|c|l|l|}
\hline $\begin{array}{c}\text { № } \\
\text { 3/п }\end{array}$ & $\begin{array}{c}\text { Найменування } \\
\text { спеціального принципу } \\
\text { системи фінансової } \\
\text { безпеки }\end{array}$ & \multicolumn{4}{|c|}{ Характеристика } \\
\hline 1 & Законність & $\begin{array}{l}\text { Діяльність всіх суб’єктів системи фінансової безпеки щодо } \\
\text { задоволення їх інтересів має здійснюватись із дотриманням } \\
\text { чинного законодавства }\end{array}$ \\
\hline 2 & Превентивність & $\begin{array}{l}\text { При функціонуванні система фінансової безпеки має } \\
\text { попереджувати негативний вплив екзогенних та ендогенних } \\
\text { чинників і загроз }\end{array}$ \\
\hline 3 & Адаптивність & $\begin{array}{l}\text { Система фінансової безпеки має бути здатною до адаптації, } \\
\text { тобто пристосування до функціонування у будь-яких умовах }\end{array}$ \\
\hline 4 & Гнучкість & $\begin{array}{l}\text { Всі елементи системи фінансової безпеки мають бути гнучими } \\
\text { до зміни зовнішнього середовища, враховуючи зміни } \\
\text { законодавства }\end{array}$ \\
\hline
\end{tabular}

Система фінансової безпеки повинна мати стратегічну та оперативну мету свого функціонування. Стратегічною метою є формування державної стратегії фінансової безпеки, яка сприятиме реалізації національних інтересів держави, і містить такі складові:

1) ідентифікація геофінансових зон впливу держави;

2) визначення об’єктів, параметрів, індикаторів та показників контролю за забезпеченням фінансової безпеки;

3) формування механізмів попередження загроз фінансовій безпеці;

4) встановлення суб’єктів загроз та зони і ступеня їх впливу на фінансовий потенціал держави;

5) нейтралізація зовнішніх та внутрішніх загроз шляхом інституційних перетворень i заходів державної фінансової політики;

6) розробка методологічної основи для прогнозування і усунення впливу факторів, що загрожують фінансовій безпеці.

Оперативною метою системи фінансової безпеки є розробка напрямів забезпечення ефективного та безпечного функціонування всіх елементів фінансової системи держави та іiі складових. Основні завдання фінансової безпеки оперативного рівня можна визначити таким чином:

1) забезпечення стійкості економічного розвитку держави;

2) нейтралізація впливу негативних екзогенних та ендогенних факторів;

3) координація дій між різними гілками влади щодо забезпечення прийнятого рівня фінансової безпеки;

4) попередження відтоку національного капіталу за кордон та відтоку капіталу з реального сектору економіки;

5) попередження злочинності та адміністративних порушень у фінансових правовідносинах.

Систему фінансової безпеки можна досліджувати в контексті іiї функцій, до яких належать: фіскальна, превентивна, стимулююча, інформаційна, правоохоронна.

Як зазначалося вище, суб'єктно-об'єктна підсистема містить рівні, суб'єкти та об'єкти фінансової безпеки. Варто зазначити, що перелік об'єктів фінансової безпеки варіюється в різних джерелах. Наприклад, I.О. Ревак до об'єктів фінансової безпеки додає: баланс доходів та видатків як державного, так і місцевих бюджетів; податкові надходження та платежі; внутрішній та зовнішній борги; розмір платіжного балансу; систему розрахунків; цінні папери; національну та іноземну валюту тощо [23]. Інший науковець - М.М. Єрмошенко [9] до переліку об'єктів фінансової безпеки зараховує: фінансовокредитну сферу в цілому як механізм і явище, на які спрямовується діяльність суб'єктів ФБД щодо забезпечення фінансової безпеки. Водночас вважаємо більш доцільною диференціацію об'єктів фінансової безпеки залежно від її визначених видів (табл. 3).

Основними видами (підсистемами) фінансової безпеки є підсистеми бюджетної, боргової, податкової, валютної, грошової та інвестиційної безпеки. Виходячи із вирізнених підсистем, можна виокремити для кожної суб'єкти та об'єкти фінансової безпеки. В цілому до суб'єктів належать органи державної влади всіх ланок, що мають відповідні компетенції у попередженні впливу зовнішніх загроз на фінансову безпеку країни. 
Важливою складовою системи фінансової безпеки є забезпечувальна підсистема, яка містить: нормативно-правове, методологічне, організаційне, інформаційне, кадрове забезпечення.

Таблиия 3

Підсистеми системи фінансової безпеки та ї̈ суб 'єкти і об 'єкти

\begin{tabular}{|c|c|c|c|}
\hline $\begin{array}{l}\text { № } \\
\text { 3/ח }\end{array}$ & Підсистеми фінансової безпеки & Суб’єкти & Об’єкти \\
\hline 1 & $\begin{array}{l}\text { Бюджетна безпека }- \text { стан фінансової } \\
\text { стійкості держави } 3 \text { урахуванням } \\
\text { збалансованості доходів і видатків } \\
\text { державного й місцевих бюджетів та } \\
\text { ефективності використання бюджетних } \\
\text { коштів }\end{array}$ & \multirow{6}{*}{$\begin{array}{c}\text { Президент, } \\
\text { Верховна Рада України, } \\
\text { Кабінет Міністрів, } \\
\text { Міністерство фінансів } \\
\text { України, } \\
\text { Національний банк } \\
\text { України, } \\
\text { Рада національної } \\
\text { безпеки та оборони } \\
\text { України, } \\
\text { Рахункова Палата, } \\
\text { Державна митна служба, } \\
\text { Державна казначейська } \\
\text { служба, } \\
\text { Державна податкова } \\
\text { служба, } \\
\text { Державна аудиторська } \\
\text { служба, } \\
\text { інвестиційні фонди, } \\
\text { комерційні банки, } \\
\text { страхові компанії, } \\
\text { Антимонопольний } \\
\text { комітет, } \\
\text { ДкцПФР }\end{array}$} & $\begin{array}{c}\text { Бюджетна система, } \\
\text { державний та місцевий } \\
\text { бюджети, } \\
\text { фінансові інтереси } \\
\text { розпорядників } \\
\text { бюджетних коштів } \\
\text { та платників податків }\end{array}$ \\
\hline 2 & $\begin{array}{l}\text { Валютна безпека }- \text { це стан } \\
\text { курсоутворення, який створює оптимальні } \\
\text { умови для розвитку вітчизняного } \\
\text { експорту, безперешкодного припливу в } \\
\text { країну іноземних інвестицій та } \\
\begin{array}{l}\text { максимально протидіє зовнішнім загрозам } \\
\text { на міжнародних валютних ринках }\end{array}\end{array}$ & & $\begin{array}{l}\text { Валютна система, } \\
\text { валютний курс, } \\
\text { обсяг іноземних } \\
\text { інвестицій, } \\
\text { фінансові інтереси } \\
\text { експортерів та } \\
\text { імпортерів } \\
\end{array}$ \\
\hline 3 & $\begin{array}{l}\text { Грошова безпека - це такий стан грошової } \\
\text { системи, який характеризується } \\
\text { стабільністю грошової одиниці та рівнем } \\
\text { інфляції, що забезпечує економічне } \\
\text { зростання держави }\end{array}$ & & $\begin{array}{c}\text { Грошово-кредитна } \\
\text { система, } \\
\text { грошова одиниця, } \\
\text { рівень інфляції }\end{array}$ \\
\hline 4 & $\begin{array}{llr}\text { Боргова безпека - рівень внутрішньої та } \\
\text { зовнішньої } & \text { заборгованості, що } \\
\text { загрожує } & \text { втратою суверенітету } \\
\text { руйнуванням } & \text { вітчизняної фінансової } \\
\text { системи } & & \end{array}$ & & $\begin{array}{c}\text { Розрахункова, } \\
\text { інвестиційна, } \\
\text { банківська, грошово- } \\
\text { кредитна система, } \\
\text { система ціноутворення } \\
\text { та їі інструменти } \\
\end{array}$ \\
\hline 5 & $\begin{array}{l}\text { Безпека страхового ринку }- \text { рівень } \\
\text { забезпеченості страхових компаній } \\
\text { фінансовими ресурсами, який надав } \\
\text { можливість відшкодувати збитки клієнтів, } \\
\text { визначені у договорах страхування без } \\
\text { втрати рівня свого потенціалу }\end{array}$ & & $\begin{array}{l}\text { Страховий ринок та } \\
\text { його послуги, } \\
\text { інструменти; } \\
\text { фінансові інтереси } \\
\text { страхувальників та } \\
\text { страховиків }\end{array}$ \\
\hline 6 & 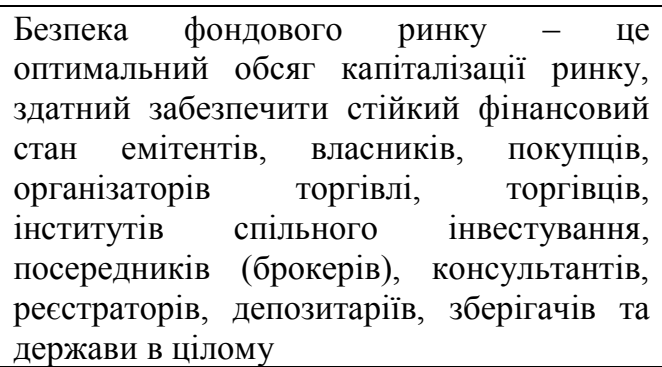 & & $\begin{array}{c}\text { Фондовий ринок, } \\
\text { його фінансові } \\
\text { інструменти; } \\
\text { фінансові інтереси } \\
\text { власників, } \\
\text { емітентів, покупців та } \\
\text { інших суб’єктів } \\
\text { фондового ринку }\end{array}$ \\
\hline
\end{tabular}

Нормативно-правове забезпечення містить законодавчі та нормативно-правові акти, які регулюють питання забезпечення фінансової безпеки в країні. До них можна зарахувати: Конституцію, Концепцію (основи державної політики) національної безпеки України, Закон України «Про основи національної безпеки України», міжнародні договори, інші нормативно-правові акти.

Методологічне забезпечення фінансової безпеки містить методичні прийоми та способи дотримання іiі на належному рівні. 
Організаційне забезпечення системи фінансової безпеки - це комплекс організаційних структур та їх взаємозв'язків, правил, процедур та заходів, які створюють умови для ефективного досягнення мети функціонування системи.

Інформаційне забезпечення системи фінансової безпеки містить сукупність інформаційних ресурсів, форм документів, нормативної бази та реалізованих рішень щодо обсягів та розміщення інформації. Це дозволяє визначити такі чотири складові в системі інформаційного забезпечення системи фінансової безпеки держави: інформаційні ресурси, інформаційні технології, технічні засоби та програмне забезпечення.

Кадрове забезпечення сформованої системи фінансової безпеки можна досліджувати у вузькому та широкому розумінні. У широкому - це діяльність, спрямована на забезпечення суб'єктів гарантування фінансової безпеки - органів державної влади, що мають відповідну компетенцію, персоналом 3 необхідним рівнем кваліфікації, навичок, професійних якостей, спроможних вирішувати поставлені завдання. У вузькому розумінні - це законодавчо закріплена та цілеспрямована діяльність таких суб'єктів (посадових осіб) щодо реалізації напрямів професійної орієнтації, планування кадрового складу, відбору та підготовки персоналу до професійної діяльності.

Досліджуючи фінансову безпеку як стан захищеності економіки від зовнішніх загроз, необхідно уточнити види загроз, які можуть містити: 1) зовнішні загрози, які потребують докладного вивчення, $\epsilon$ такими: а) глобалізація та становлення глобальної світогосподарської системи; б) діяльність ТНК, які мають значну фінансову владу та впливають на економіки окремих країн; в) надмірна залежність від іноземного капіталу; г) значний рівень концентрації фінансових ресурсів як на рівні макроекономічному (враховуючи бюджетні системи держав та міжнародних фінансових організацій), так і на глобальному (різні форми міждержавної економічної інтеграції); д) високий динамізм фінансових ринків та їх тісний взаємозв'язок; ж) розвиток фінансових інструментів, які використовуються суб'єктами фінансових відносин; з) зростаючий вплив світових фінансів на зовнішню та внутрішню політику окремих держав; к) посилення конкуренції між окремими державами у фінансовій та економічній сферах; л) нестійкість світової фінансової системи та обмежена можливість впливу державних фінансових інститутів на світові кризові тенденції.

Однак поряд 3 наявністю зовнішніх загроз фінансовій безпеці, існує низка загроз внутрішнього характеру, до яких належать: а) неефективна фінансова політика держави; б) зловживання окремих суб'єктів фінансових відносин; в) відсутність результативної системи державного фінансового контролю; г) інші прорахунки, обумовлені неефективними діями керівників держави тощо. Перераховуючи види загроз фінансовій безпеці України, Н.Наконечна визначає:

1) недостатність фінансових ресурсів у суб'єктів господарювання для забезпечення відтворювального процесу;

2) незавершеність законодавства у фінансовій сфері;

3) слабкість грошово-кредитної системи;

4) відсутність цілісної стратегії іноземного інвестування;

5) низький рівень соціально-трудових відносин, соціальної спрямованості економіки;

6) незбалансованість структури зовнішньої торгівлі, значний обсяг зовнішнього боргу [17, с. 285].

Важливим складовим елементом системи фінансової безпеки $є$ індикатори та критерії іiі забезпечення, що можна сформувати як критеріальну базу забезпечення належного рівня фінансової безпеки (табл. 4).

Окреслюючи різноспрямованість позицій щодо переліку індикаторів фінансової безпеки, вважаємо за потрібне їх диференціювати залежно від іiі виокремлених рівнів (бюджетна, боргова, грошова, валютна, безпека страхового ринку, безпека фондового ринку).

Таблиия 4

Критеріальна база (індикатори) забезпечення належного рівня фінансової безпеки держави

\begin{tabular}{|c|c|l|}
\hline $\begin{array}{c}\text { № } \\
\text { 3/п }\end{array}$ & \multicolumn{1}{|c|}{ Автори } & \multicolumn{1}{|c|}{ Індикатори } \\
\hline 1 & 2 & \multicolumn{1}{|c|}{3} \\
\hline 1 & O.І. Барановський [1] & $\begin{array}{l}\text { Індикатори фінансової безпеки громадян; домашніх господарств; } \\
\text { підприємств, організацій і установ; галузей; регіонів; банківської } \\
\text { системи; фондового ринку; держави }\end{array}$ \\
\hline \multirow{2}{*}{$\begin{array}{l}\text { М.М. Срмошенко } \\
\text { [8; 9] }\end{array}$} & $\begin{array}{l}\text { Вомремлюють такі групи показників: 1) показники реального й } \\
\text { бюджетного сектору; 3) індикатори державного боргу; 4) індикатори } \\
\text { грошово-кредитного сектору; 5) індикатори інфляції; 6) індикатори } \\
\text { інвестиційної сфери; 7) індикатори валютного ринку; 8) індикатори } \\
\text { фондового ринку }\end{array}$ \\
\hline
\end{tabular}


Закінчення табл. 4

\begin{tabular}{|c|c|c|}
\hline 1 & 2 & 3 \\
\hline 3 & І.Ластовченко [13] & $\begin{array}{l}\text { Система фінансових показників враховує макроекономічні, зведені й } \\
\text { індивідуальні критерії та показники. Макроекономічні: загальний } \\
\text { обсяг фінансових ресурсів; загальний обсяг доходів бюджетів; } \\
\text { загальний обсяг видатків бюджетів; загальну величину зовнішнього } \\
\text { та внутрішнього боргу; загальний обсяг грошових надходжень; } \\
\text { загальний обсяг страхових і резервних фондів. Зведені показники } \\
\text { поділяють: на зведені показники загальнодержавного рівня (витрати } \\
\text { зведеного бюджету за основними напрямами витрат); показники, що } \\
\text { характеризують фінанси економіки в цілому або окремих підрозділів; } \\
\text { показники фінансового ринку }\end{array}$ \\
\hline 4 & $\begin{array}{c}\text { В.Шлемко } \\
\text { та І.Бінько [29] }\end{array}$ & $\begin{array}{l}\text { Дефіцит Державного бюджету; рівень перерозподілу ВВП через } \\
\text { зведений бюджет України; рівень монетизації ВВП; ступінь } \\
\text { доларизації національної економіки; швидкість обігу готівки; } \\
\text { відсоткова ставка за банківський кредит; ставка рефінансування НБУ; } \\
\text { відношення суми валових міжнародних резервів НБУ до загальної } \\
\text { суми річного імпорту; валютний курс; питома вага довгострокових } \\
\text { банківських кредитів у загальному обсязі наданих кредитів; } \\
\text { відношення суми власних обігових коштів підприємств до суми } \\
\text { залучених обігових коштів; питома вага податків в обсязі ВВП }\end{array}$ \\
\hline 5 & Н.В. Наконечна [17] & $\begin{array}{l}\text { Рівень перерозподілу ВВП через Зведений бюджет України; рівень } \\
\text { монетизації ВВП; дефіцит Державного бюджету; ступінь доларизації } \\
\text { національної економіки; швидкість обігу готівки; процентна ставка за } \\
\text { банківський кредит; ставка рефінансування НБУ; валютний курс; } \\
\text { питома вага довгострокових банківських кредитів у загальному обсязі } \\
\text { наданих кредитів; питома вага податків в обсязі ВВП }\end{array}$ \\
\hline 6 & $\begin{array}{l}\text { Методика розрахунку } \\
\text { рівня економічної } \\
\text { безпеки України } \\
\text { (Наказ Міністерства } \\
\text { економіки України } \\
\text { від 02.03.2007 p. } \\
\text { № 60) [20] }\end{array}$ & $\begin{array}{l}\text { Індикатори поділяються на такі групи: 1) бюджетної безпеки; } \\
\text { 2) безпеки грошового ринку та інфляційних процесів; 3) валютної; } \\
\text { 4) боргової; 5) страхового ринку; 6) фондового ринку }\end{array}$ \\
\hline
\end{tabular}

За класифікацією систем означена система фінансової безпеки є: 1) великою, оскільки вона не може досліджуватися жодним чином, лише як сукупність апріорно виокремлених підсистем; 2) складною системою, що обумовлено наявністю значної кількості підсистем та об'єктів фінансової безпеки; 3) динамічною системою, яка постійно трансформується під впливом зовнішнього середовища; 4) цілеспрямованою підсистемою, тобто управління системою фінансової безпеки спрямовує іiі до визначеного стану, компенсуючи вплив зовнішніх загроз.

Висновки та перспективи подальших наукових досліджень. Аналіз категоріально-понятійного апарату фінансової безпеки дозволив сформувати такі концептуальні підходи до трактування ії сутності: 1) суб'єктний підхід; 2) об’єктний підхід; 3) інституціональний; 4) системний. Обгрунтовано, що методологічною основою дослідження фінансової безпеки доцільно обрати системний підхід, що обумовлено важливістю її вивчення як складного взаємозв'язку окремих підсистем, рівнів та елементів системи, що надасть можливість досягнути позитивного системного ефекту. Сформовано концептуальні засади формування системи фінансової безпеки, яка складається з трьох взаємопов'язаних підсистем: 1) функціонально-цільової, яка містить принципи, мету (стратегічну та оперативну), завдання та функції системи фінансової безпеки; 2) суб'єктно-об'єктної (рівні, суб'єкти та об'єкти фінансової безпеки, диференційовані за виокремленими рівнями); 3) забезпечувальної підсистеми, яка містить кадрове, нормативно-правове, методологічне, організаційне та інформаційне забезпечення. Входом запропонованої системи є фактори зовнішнього середовища, під впливом яких вона трансформується, виходом - індикатори та показники, що дозволяють оцінити дієвість системи.

Перспективи подальших наукових досліджень варто пов'язати із детальним вивченням елементів запропонованої структури та визначенням системного ефекту від їх взаємодії. 
Список використаної літератури:

1. Барановський O.I. Фінансова безпека в Україні (методологія оцінки та механізми забезпечення) / О.I. Барановський. - К. : КНТЕУ, 2004. - 759 с.

2. Boyes W. Economics: Ninth Edition / W.Boyes, M.Melvin // South-Western, Cengage Learning, 2013. -371 p.

3. Bradlow D. Reforming the Global Financial Architecture: Is Real Change Coming? / D.Bradlow [Electronic recourse]. Access mode $:$ http://digitalcommons.wcl.american.edu/cgi/viewcontent.cgi?article $=1018 \&$ context= fac_works_papers.

4. Бурцев В. Факторы финансовой безопасности России / В.Буриев // Менеджмент в России и за рубежом, 2001. - № 1 [Електронний ресурс]. - Режим доступу : https://www.cfin.ru/press/management/2001$1 /$ burtsev.shtml.

5. Виговська Н.Г. Місце зовнішнього державного фінансового контролю у національній контрольній системі України / Н.Г. Виговська, А.Ю. Славіцька // Вісник ЖДТУ. Серія : Економічні науки. - 2016. - № 4 (78). C. 219-228.

6. Clark C. Conditions of Economic Progress / C.Clark. - London : Macmillan, 1940.

7. Гривківська О.В. Забезпечення фінансової безпеки сільського господарства / О.В. Гривківська. - Тернопіль : Астон, 2012. - $340 \mathrm{c}$.

8. Засади формування бюджетної політики держави : монографія / за наук. ред. М.М. Єрмошенка. - К. : НАУ, 2003. - 284 c.

9. Срмошенко М.M. Фінансова безпека держави: національні інтереси, реальні загрози, стратегія забезпечення / М.М. Срмошенко. - К. : Київський нац. торг.-екон. ун-т, 2001. - 309 с.

10. Кондрат E.H. Значение финансового контроля в системе финансовой безопасности государства / E.H. Кондрат [Електронний ресурс]. - Режим доступу : https://cyberleninka.ru/article/n/znacheniefinansovogo-kontrolya-v-sisteme-finansovoy-bezopasnosti-gosudarstva.

11. Койло B.B. Формування фінансової безпеки України під впливом залучення кредитних ресурсів міжнародних фінансових організацій : автореф. дис. на здобуття наук. ступеня канд. екон. наук : спец. 08.00.08 / В.В. Койло. - Суми : Сумський державний університет, 2018. - 19 с.

12. Крюкова I.O. Імплементація потокових концепцій у науково-методичні аспекти управління фінансовою безпекою підприємств АПВ / І.О. Крюкова, Н.В. Лагодієнко // Проблеми і перспективи економіки та управління. - 2015. - № 2 (2). - С. 212-218.

13. Ластовченко І.В. Фінансові показники як основа механізму регулювання економіки / I.B. Ластовченко // Фінанси України. - 1998. - № 3. - С. 73-80.

14. Myers S.C. Financial architecture / S.C. Myers // European Financial Management. - 1999. - Vol. 5. - № 2. P. 133-141.

15. Мелих О.В. Фінансова безпека держави: сутність, критерії оцінки та превентивні заходи зміцнення / О.В. Мелих // Економічний аналіз. - 2013. - Вип. 12. - Ч. 2. - С. 266-272.

16. Мельник B.M. Фінансова архітектура національних корпорацій та ії вплив на ефективність фінансової діяльності / В.М. Мельник. - Тернопіль : Астон, 2012. - 244 с.

17. Наконечна Н.В. Методологічні підходи щодо оцінювання рівня фінансової безпеки України / Н.В. Наконечна // Науковий вісник НЛТУ України. - 2013. - Вип. 23. - С. 281-287.

18. Новосад I. Митна безпека як важлива складова економічної безпеки держави / I.Новосад // Світ фінансів. 2015. - № 2. - С.145-153.

19. Попов В.M. Системный анализ в управлении социально-экономическими процессами / B.M. Попов, Г.П. Солодков, В.М. Топилин. - Ростов на-Дону : СКАГС, 2002. - 501 с.

20. Про схвалення Концепції забезпечення національної безпеки у фінансовій сфері : розпорядження Кабінету Міністрів України від 15.08.2012 № 569 [Електронний ресурс]. - Режим доступу http://www.minfin.gov.ua/control/uk/publish/article\%3Fart_id=352861\&cat_id=54063.

21. Райзберг Б.А. Современный экономический словарь / Б.А. Райзберг, Л.Ш. Лозовский, Е.Б. Стародубиева. М. : ИНФРА-М, 2019. - 512 c.

22. Rajsingh P.V. The global financial crisis and neo-liberal financialization Critical Studies on Corporate Responsibility / P.V. Rajsingh // Governance and Sustainability. - 2016. - № 11. -P. 57-73.

23. Ревак I.O. Суб'єкти та об'єкти фінансової безпеки - базові складові фінансової безпеки держави / I.O. Ревак // Вісник економіки транспорту i промисловості. - 2010 [Електронний ресурс]. - Режим доступу : https://cyberleninka.ru/article/n/objects-and-subjects-to-financial-safety-a-base-component-systems-to financial-safety-state.

24. Ross L. Financial Development and Economic Growth: Views and Agenda / L.Ross // Journal of Economic Literature. - 1997. - № 35 (2). - P. 688-726.

25. Савицька О. Оцінка та шляхи забезпечення фінансової безпеки України / O.Савицька // Економічний форум. - 2012. - № 3. $-14 \mathrm{c}$.

26. Синчак В.П. Фінансова безпека сільськогосподарських підприємств / В.П. Синчак // Вісник Сумського національного аграрного університету. Серія : Фінанси і кредит. - 2009. - № 2. - С. 45-49.

27. Сухоруков A.I. Проблеми фінансової безпеки України / А.І. Сухоруков. - К. : НІПМБ, 2004. - 117 с.

28. Schinasi G.J. Defining Financial Stability / G.J. Schinasi // IMF Working Paper. - 2004. - October. - 19 p.

29. Шлемко B.T. Економічна безпека України: сутність і напрямки забезпечення / В.T. Шлемко, I.Ф. Бінько. К. : НІСД, 1997. - 144 c.

30. The effect of it-transformation of the country's financial potential during the post-conflict reconstruction / N.Vyhovska, A.Polchanov, S.Frolov, Y.Kozmenko // Public and Municipal Finance. - 2018. - Vol. 7, Issue 3. P. 15-25. 


\section{References:}

1. Baranovs'kyj, O.I. (2004), Finansova bezpeka v Ukrai'ni (metodologija ocinky ta mehanizmy zabezpechennja), KNTEU, Kyi'v, 759 p.

2. Boyes, W. and Melvin, M. (2013), Economics: Ninth Edition, South-Western, Cengage Learning, 371 p.

3. Bradlow, D. Reforming the Global Financial Architecture: Is Real Change Coming?, [Online], available at: http://digitalcommons.wcl.american.edu/cgi/viewcontent.cgi?article $=1018 \&$ context $=$ fac_works_papers

4. Burcev, V. (2001), «Faktory finansovoj bezopasnosti Rossii», Menedzhment v Rossii i za rubezhom, No. 1, [Online], available at: https://www.cfin.ru/press/management/2001-1/burtsev.shtml

5. Vygovs'ka, N.G. and Slavic'ka, A.Ju. (2016), «Misce zovnishn'ogo derzhavnogo finansovogo kontrolju u nacional'nij kontrol'nij systemi Ukrai'ny», Visnyk ZhDTU, Serija Ekonomichni nauky, No. 4 (78), pp. $219-228$.

6. Clark, C. (1940), Conditions of Economic Progress, Macmillan, London.

7. Gryvkivs'ka, O.V. (2012), Zabezpechennja finansovoi' bezpeky sil's'kogo gospodarstva, Aston, Ternopil', 340 p.

8. Jermoshenka, M.M. (ed.) (2003), Zasady formuvannja bjudzhetnoi' polityky derzhavy, monografija, NAU, Kyi'v, 284 p.

9. Jermoshenko, M.M. (2001), Finansova bezpeka derzhavy: nacional'ni interesy, real'ni zagrozy, strategija zabezpechennja, Kyi'vs'kyj nac. torg.-ekon. un-t, Kyi'v, 309 p.

10. Kondrat, E.N. Znachenye finansovogo kontrolja v systeme fynansovoj bezopasnosty gosudarstva, [Online], available at: https://cyberleninka.ru/article/n/znachenie-finansovogo-kontrolya-v-sisteme-finansovoy-bezopasnosti-gosudarstva

11. Kojlo, V.V. (2018), Formuvannja finansovoi' bezpeky Ukrai'ny pid vplyvom zaluchennja kredytnyh resursiv mizhnarodnyh finansovyh organizacij, Abstract of Ph.D. dissertation, spec. 08.00.08, Sums'kyj derzhavnyj universytet, Sumy, 19 p.

12. Krjukova, I.O. and Lagodijenko, N.V. (2015), «Implementacija potokovyh koncepcij u naukovo-metodychni aspekty upravlinnja finansovoju bezpekoju pidpryjemstv APV», Problemy i perspektyvy ekonomiky ta upravlinnja, No. 2 (2), pp. 212-218

13. Lastovchenko, I.V. (1998), «Finansovi pokaznyky jak osnova mehanizmu reguljuvannja ekonomiky», Finansy Ukrai'ny, No. 3, pp. 73-80.

14. Myers, S.C. (1999), «Financial architecture», European Financial Management, Vol. 5, No. 2, pp. $133-141$.

15. Melyh, O.V. (2013), «Finansova bezpeka derzhavy: sutnist', kryterii' ocinky ta preventyvni zahody zahody zmicnennja», Ekonomichnyj analiz, Issue 12, Chapter 2, pp. 266-272.

16. Mel'nyk, V.M. (2012), Finansova arhitektura nacional'nyh korporacij ta i'i' vplyv na efektyvnist' finansovoi' dijal'nosti, Aston, Ternopil', $244 \mathrm{p}$

17. Nakonechna, N.V. (2013), «Metodologichni pidhody shhodo ocinjuvannja rivnja finansovoi' bezpeky Ukrai'ny», Naukovyj visnyk NLTU Ukrai'ny, Issue 23, pp. 281-287.

18. Novosad, I. (2015), «Mytna bezpeka jak vazhlyva skladova ekonomichnoi' bezpeky derzhavy», Svit finansiv, No. 2, pp.145-153.

19. Popov, V.M., Solodkov, G.P. and Topilin, V.M. (2002), Sistemnyj analiz v upravlenii social'no-jekonomicheskimi processami, SKAGS, Rostov na-Donu, 501 p.

20. Kabinet Ministriv Ukrai'ny (2012), Pro shvalennja Koncepcii' zabezpechennja nacional'noi' bezpeky u finansovij sferi, rozporjadzhennja vid 15.08.2012, № 569, [Online], available at: http://www.minfin.gov.ua/control/uk/publish/article\%3Fart_id=352861\&cat_id=54063

21. Rajzberg, B.A., Lozovskij, L.Sh. and Starodubceva, E.B. (2019), Sovremennyj jekonomicheskij slovar', INFRA-M, M., $512 \mathrm{p}$.

22. Rajsingh, P.V. (2016), «The global financial crisis and neo-liberal financialization Critical Studies on Corporate Responsibility», Governance and Sustainability, No. 11, pp. 57-73.

23. Revak, I.O. (2010), «Sub'jekty ta ob'jekty finansovoi' bezpeky - bazovi skladovi finansovoi' bezpeky derzhavy», Visnyk ekonomiky transportu i promyslovosti, [Online], available at: https://cyberleninka.ru/article/n/objects-andsubjects-to-financial-safety-a-base-component-systems-to financial-safety-state

24. Ross, L. (1997), «Financial Development and Economic Growth: Views and Agenda», Journal of Economic Literature, No. 35 (2), pp. 688-726.

25. Savyc'ka, O. (2012), «Ocinka ta shljahy zabezpechennja finansovoi' bezpeky Ukrai'ny», Ekonomichnyj forum, No. 3, 14 p.

26. Synchak, V.P. (2009), «Finansova bezpeka sil's'kogospodars'kyh pidpryjemstv», Visnyk Sums'kogo nacional'nogo agrarnogo universytetu, Serija Finansy i kredyt, No. 2, pp. 45-49.

27. Suhorukov, A.I. (2004), Problemy finansovoi' bezpeky Ukrai'ny, NIPMB, K., 117 p.

28. Schinasi, G.J. (2004), «Defining Financial Stability», IMF Working Paper, from October, 19 p.

29. Shlemko, V.T. and Bin'ko, I.F. (1997), Ekonomichna bezpeka Ukrai'ny: sutnist' i naprjamky zabezpechennja, NISD, K., 144 p.

30. Vyhovska, N., Polchanov, A., Frolov, S. and Kozmenko, Y. (2018), «The effect of it-transformation of the country's financial potential during the post-conflict reconstruction», Public and Municipal Finance, Vol. 7, Issue 3, pp. 15-25.

Костишин Юрій Сергійович - аспірант кафедри фінансів і кредиту Державного університету «Житомирська політехніка».

Наукові інтереси:

- фінансова безпека;

- митний контроль. 